\title{
Preliminary experimental insights into differential heat impact among lithic artifacts
}

\author{
Guillermo Bustos-Pérez, Javier Baena Preysler \\ Universidad Autónoma de Madrid, Departamento de Prehistoria y Arqueología, \\ Campus de Cantoblanco, 28049 Madrid, Spain. \\ Email: Bustos-Pérez: guillermo.bustos@estudiante.uam.es; Baena Preysler: javier.baena@uam.es
}

\begin{abstract}
:
The presence of thermally altered and broken flint artifacts is common at archaeological sites. Most studies focus their attention on the effects of heat treatment on flint to improve knapping qualities, disregarding the effects of fire over flint under uncontrolled conditions. This paper aims to show how under uncontrolled heating processes flint artifacts develop different heat alterations (such as levels of breakage, presence of scales, etc.) as a result of vertical distribution, volume or raw material and to establish a gradient of rock changes and behavior. Artifacts where macroscopically analyzed and a series of uncontrolled heating experiments through the distribution of flint blanks under two hearths were carried out, allowing a comparison of the before and after of the blanks. Preliminary results show how levels of breakage, surface alteration or development of heat alteration features can be differentiated according to artifact volume, vertical distribution and level of surface alteration. Results also show how two different raw materials react differently to similar thermal impact, and how surface alteration reacts at different rhythm in the case of recycled artifacts. We conclude that levels of thermal alteration can be differentiated through macroscopic analysis of flint surface.
\end{abstract}

Keywords: lithic studies; heat alterations; breakage; experimental archaeology; hearths

\section{Introduction}

Since the emergence of use of fire (Roebroeks \& Villa 2011), hearths have been more or less present at archaeological sites, and along with them the presence of burnt, broken or heat altered flint artifacts. This relationship between hearths and heat altered artifacts is explained on the basis that hearths play a key role on site organization: they have a gravitational effect on artifact deposition (Simek 1984); they are central the organization of space and activities on a site; and are even used as waste dumps (Binford 1988; Vaquero \& Pastò 2001; Henry 2012; as some examples). Also, artifacts buried long time ago can suffer heat impact from hearths situated above (example Vaquero et al. 2012). Some examples of the importance of hearths at archaeological sites can be found at Israel (Shea 2003; Karkanas et al. 2007; Blasco et al. 2014); or Europe (Roebroeks \& Villa 2011; Fernández Peris et al. 2012; Aldeias et al. 2012; Goldberg et al. 2012; Vaquero \& Pastò 2001; Mallol et al. 2013; Ortiz \& Baena 2015).

Published by the School of History, Classics and Archaeology, University of Edinburgh ISSN: 2055-0472. URL: http://journals.ed.ac.uk/lithicstudies/

This work is licensed under a Creative Commons Attribution 2.5 UK: Scotland License. 
Thus, it is quite common that stone artifacts would be unconsciously altered by heat impact in different ways and without looking for increasing knapability.

Despite heat alteration and breakage are common at archaeological sites; most of the heating experiments have been focused on recognizing heat treatment and its effects in improving flint knapping qualities (Crabtree \& Butler 1964; Borradaile et al. 1993; Web \& Domansky 2009; Schmidt et al. 2012) although an increasing amount of literature referring to unintentional heat alterations exists (Patterson 1995; Mercierca 2000; Dorta et al. 2010; Frick et al. 2012). The aim of this paper is to show how under uncontrolled heating conditions flint blanks may react differently according to their volume, deepness beneath a hearth, or raw material composition. Also, a complete record of heat alterations generated by fire is provided along with a new macroscopic classification of surface alteration levels.

\section{Material and methods}

To experimentally test the differential effects of fire on blanks from a vertical point of view and according to blank volume and raw material, a sample of 158 flint blanks was selected. Of these, 79 belonged to Bergerac flint and 79 belonged to South Madrid Miocene Flint (SMM henceforth). The different varieties of Bergerac (Fernandes et al. 2012) flint are characterized by a packstone texture, a small grain size (between $200 \mu \mathrm{m}$ and $300 \mu \mathrm{m}$ ) that are well classified and a subangular form. Bergerac flint is mainly composed by chalcedony $\left(\mathrm{SiO}_{2}\right)$ covered by detritic quartz grains that present similar sizes, and varying portions of opal (5/25\%). Bergerac flint was chosen because of its homogeneity and excellent knapping qualities that are considered will better reflect thermal alterations. SMM flint (Bustillo \& Pérez-Jiménez 2005; Bustillo et al. 2012) is mainly composed of chalcedony ( 90\%) with different percentages of opals (10\%) forming crystal mosaic structure that vary in sizes (macrocrystal to microcrystal), were grain size ranges between $250 \mu \mathrm{m}$ and $500 \mu \mathrm{m}$. SMM flint was chosen because of its internal heterogeneity that can present poorly grained sandy surfaces and a medium and high quality for knapping (as a result of depositional environment and erosion).

Analysis of pre-altered flint samples included basic dimensional measures (length, width and thickness), weight, and macroscopic and detail photos of surface (using a Nikon D5100 DSLR Camera and a Motic SMZ-171 Zoom Stereo Microscope). To approach heat impact from a volumetric point of view, volume of blanks was calculated using the formula $V=\pi r^{2} h$ (blanks were placed in a graduated cylinder, measuring height of water displacement).

Since previous works (Mercieca 2000; Mercieca \& Hiscock 2008) have shown that blanks with a volume under $3 \mathrm{~cm}^{3}$ are hardly altered, a histogram analysis was carried out for blanks with a volume higher than $3 \mathrm{~cm}^{3}$, obtaining four volumetric categories for each flint (Figure 1). However volume is a measure related with blank length, width, and especially blank thickness, and thickness is also related with the development of heat alterations (thickness affects ability to evaporate water and differential dilatation). Therefore it is important to ensure that increasing volume is well correlated with increasing thickness. Figure 2 shows that cluster grouping according to blank thickness is similar to volume cluster of Figure 1, indicating that increasing volume is related to increasing thickness. Also statistical analysis shows a good correlation between the volume and thickness of booth types of flint blanks ( $\mathrm{p}=<0.0005 \mathrm{r}^{2}=0.664$ in the case of Bergerac flint blanks; $\mathrm{p}=<0.0005 \mathrm{r}^{2}=0.710$ in the case of SMM flint blanks). Blanks where distributed according to their volume cluster grouping, keeping a similar volume composition between layers (Figure 1). 

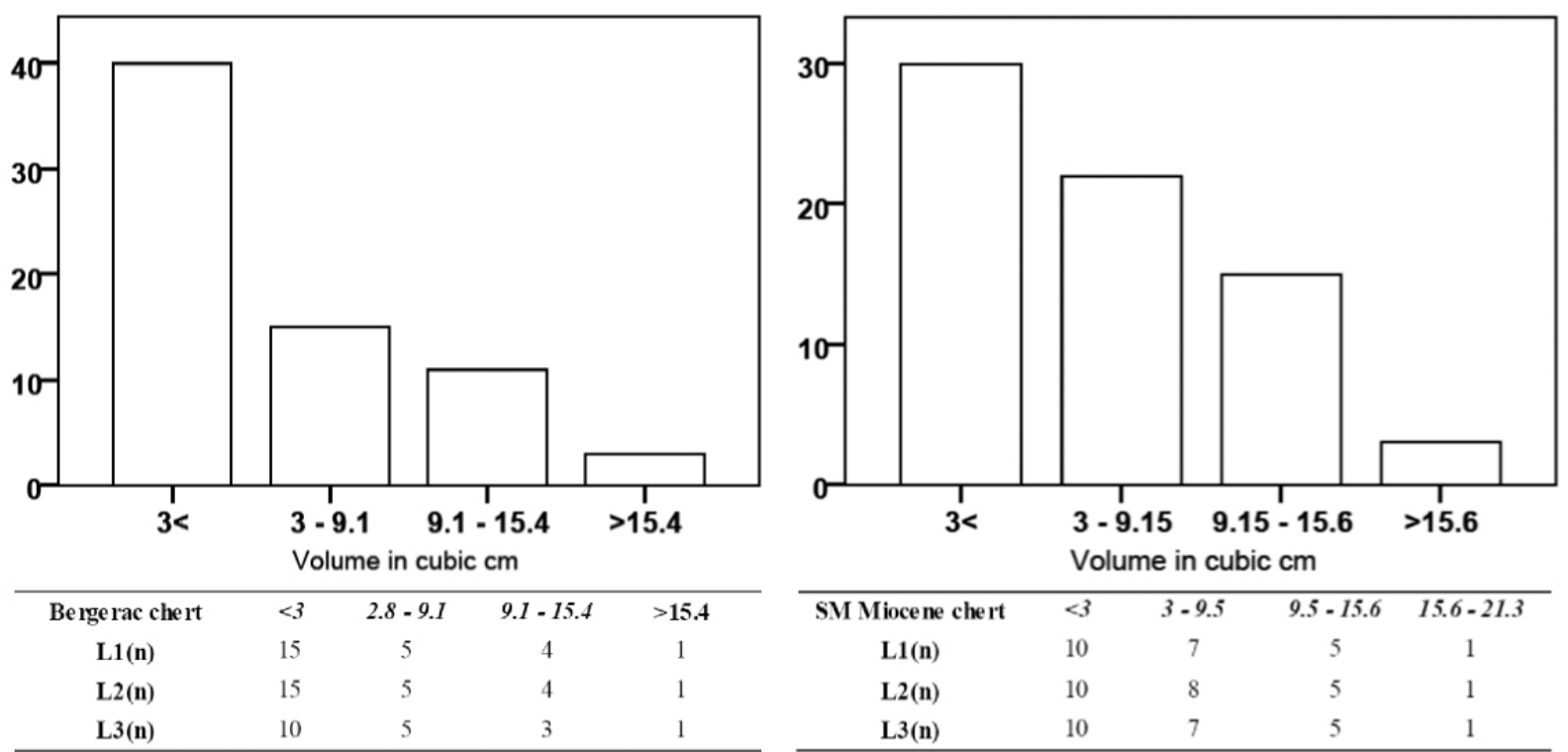

Figure 1. Volumetric distribution of blanks according to histogram results for blanks with a volume higher than 3 $\mathrm{cm}^{3}$ and distribution among layers
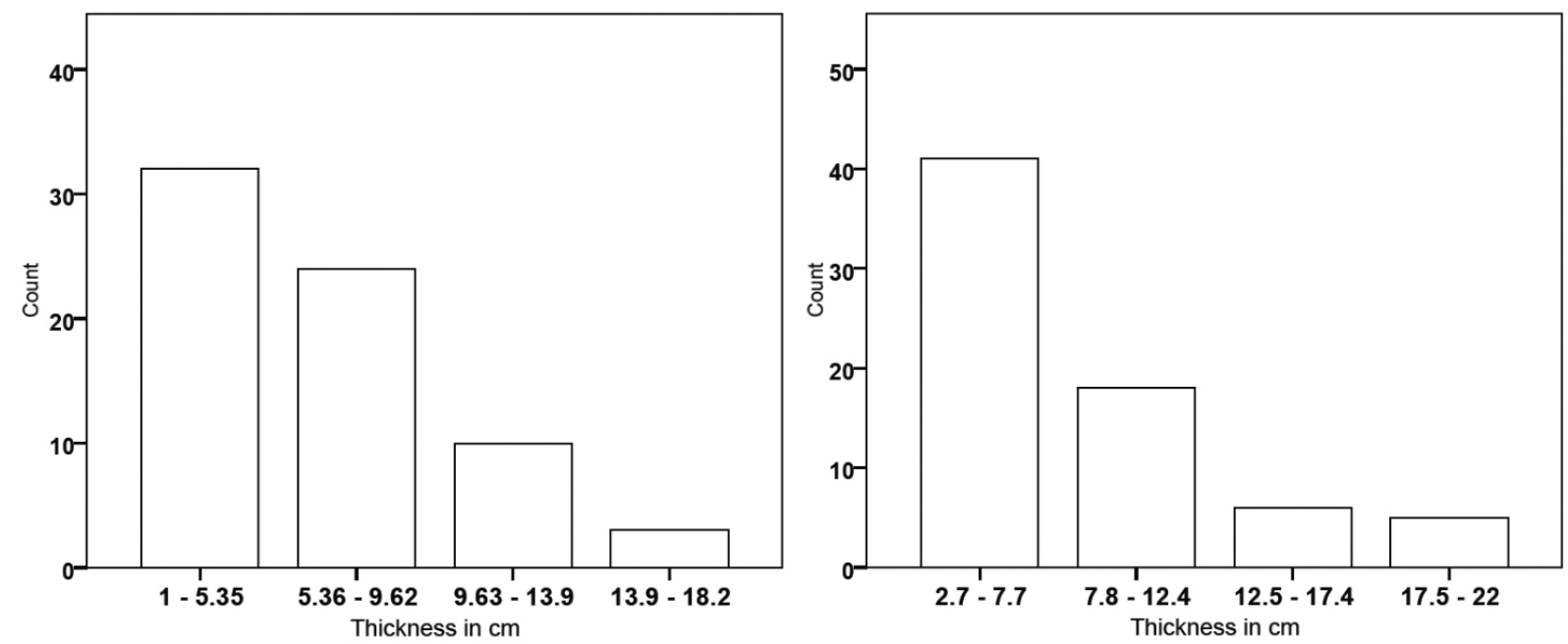

Figure 2. Histogram analysis for average blank thickness for Bergerac flint (left) and SMM flint (right).

Three experimental fires were set-up (called hearth 1, 2 and 3). Hearth 1 and 2 were prepared to test differential heat impact, while hearth 3 was prepared to test recycling experiments and to test SMM flint blanks directly thrown to fire. Fires were conducted at open air and located at similar settings where ventilation through wind is present and soil is mainly composed of dry sandy clay. Flint blanks were distributed in three levels: layer 1 corresponds to surface; layer 2 corresponds to $2.5 \mathrm{~cm}$ below surface; and layer 3 corresponds to $5 \mathrm{~cm}$ below surface (to secure distance from surface and between layers a home-made sounding system was used). Main fuel was composed of Quercus ilex wood and logs never exceeded $7 \mathrm{~cm}$ of diameter, having each hearth a fuel weight between 5.8 and $5.2 \mathrm{~kg}$. Fires were started in the morning and were let to burn down naturally. Temperature of the surface of the hearth was measured using a laser pyrometer (PCE-880), measuring average temperature of the highest point every three minutes during four hours. If fires were not dead in the afternoon, they were cooled by covering them with sand and in the next morning blanks were recovered. Blanks were analyzed recording heat alterations and fracture types (Figures 3 and 4) in a presence or absence table. The recognition of these taphonomic features is based 
in previous works (Inizan et al. 1995: 93-95; Patterson 1995; Clemente-Conte 1995; 1997; Hiscock 2002):

- Longitudinal fractures: those that split the blank through the longitudinal axe, bearing both in the proximal side presence of percussion platform.

- Transversal fractures: those that split the blank in an axes transversal or semi transversal to percussion edge retaining portions of both lateral margins.

- Marginal fractures: those that only contain presence of only one lateral margin.

- Internal cracking: macroscopic alterations that vary in shape, size and deepness. They present a distinguishable reticular shape.

- Scales: macroscopic alterations that vary in shape, size and deepness. They are defined by a curvilinear shape. If development of the scale continues it becomes a thermal bubble or extraction.

- Thermal bubbles or pot-lids: negative of the detachment of small flakes or fragments as a result of extreme development of scales. Size and deepness might vary, but they have a characteristic oval or spherical shape, and negatives leave the characteristic thermal gloss with a rough or smooth surface.
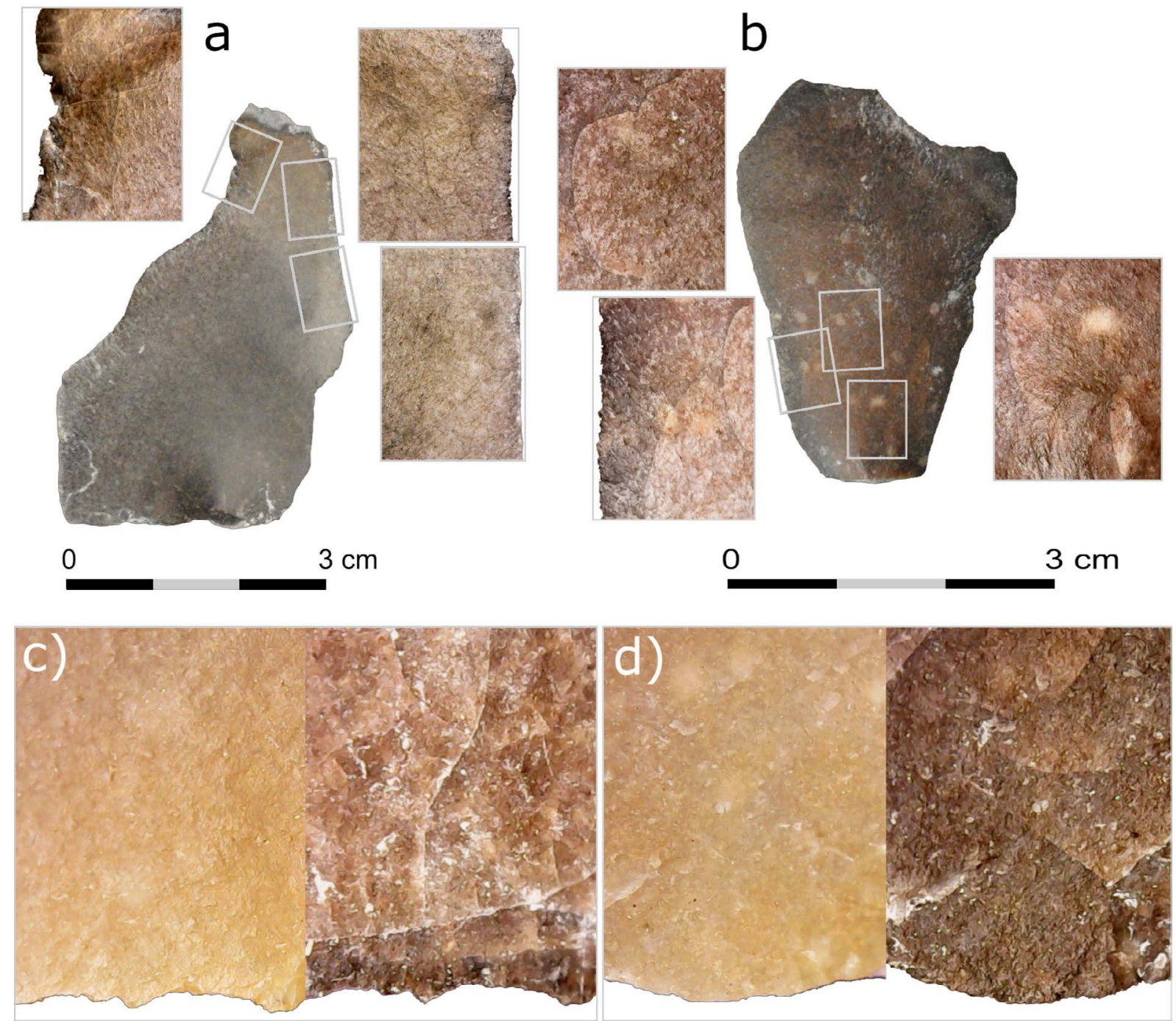

Figure 3. Samples of heat alterations: a) samples of internal cracking on the surface of the blank seen from a macroscopic view; b) development of scales on the surface of the blank seen from a macroscopic view; c) detail photo of the development of internal cracking; d) detail photo of the development of scales. 

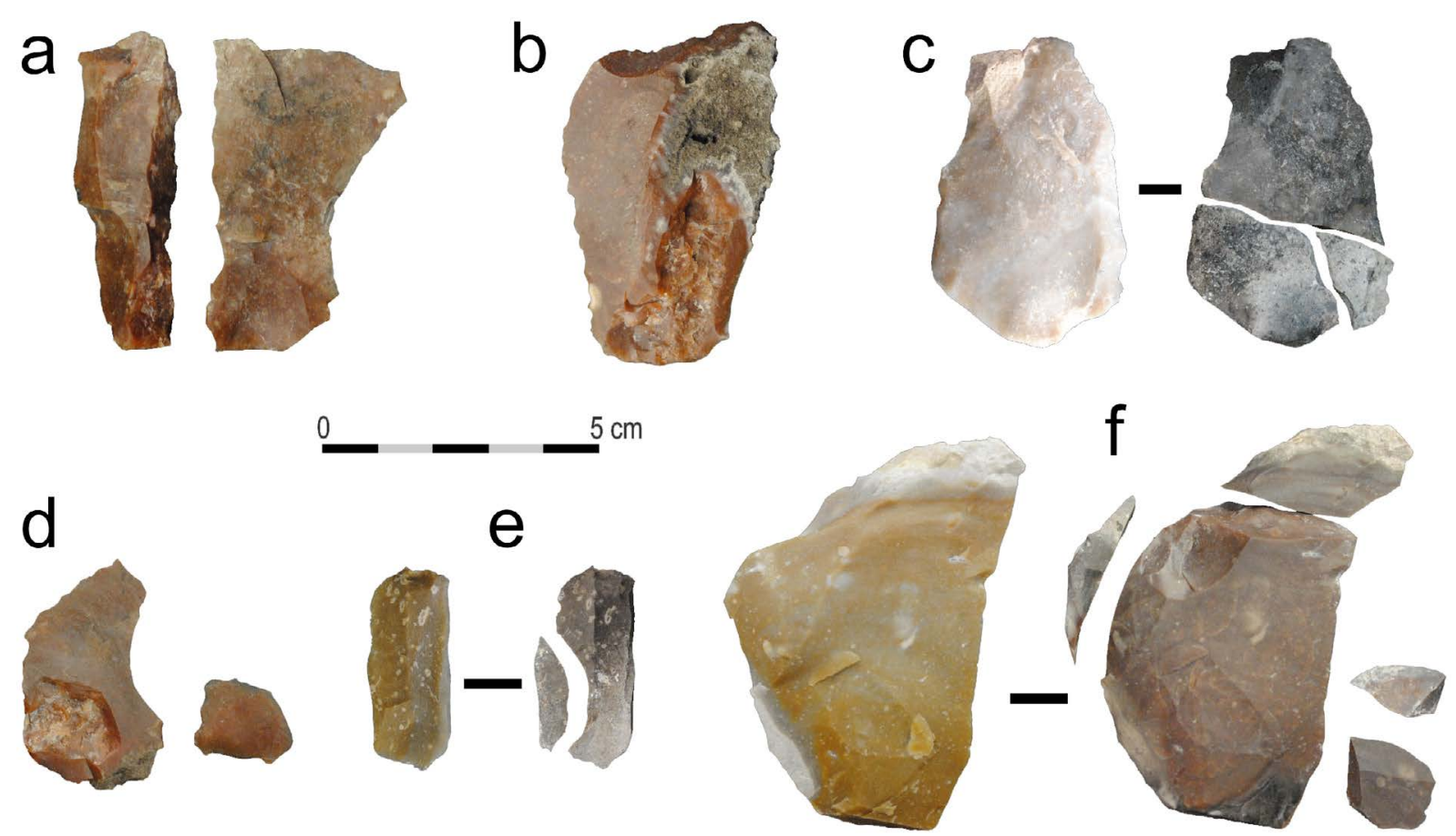

Figure 4. Samples of some heat alterations analyzed along the experimental record: a) longitudinal fracture; b and d) thermal bubble or pot-lids; c and f) marginal and transversal fractures

An important effect of heat alteration is the impact over the surface of a blank. This impact usually presents a series of features that are developed in a more or less intense way (Patterson 1995; Howard 2002; Fukuda \& Nakashima 2008). For this work, a series of surface alteration levels (henceforth SAL) of flint were defined after analyzing flint blanks and taking in account inferred level of dehydration, surface texture, and associated diagnostic colors (Figures 5 and 6 as examples). It is important to consider that SAL may be related or not to other heat alterations such as thermal bubbles or pot-lids, scales or internal cracking. Because heat alterations usually affect the blank as a hole, it has been considered that SAL exclude each other:

- Surface alteration level 0: no visible changes are present.

- Surface alteration level 1: dehydration lightly present or absent. Color changes may be present, associated with the original color and waxy luster might be developed in a more or less intense way.

- Surface alteration level 2: dehydration is present along with color changes. Dehydration generates a contraction, increasing the visibility of topographic surface and giving it a rough appearance. Waxy luster may be present in different intensities.

- Surface alteration level 3: highly dehydrated, color changes have been blackened (associated with carbonization). As a consequence, the characteristic waxy luster has been partially or completely lost and surface presents a rough appearance.

- Surface alteration level 4: highly dehydrated, color changes have been bleached (associated with color white of incineration), and as a result, surface might present a rough, spongy surface. 

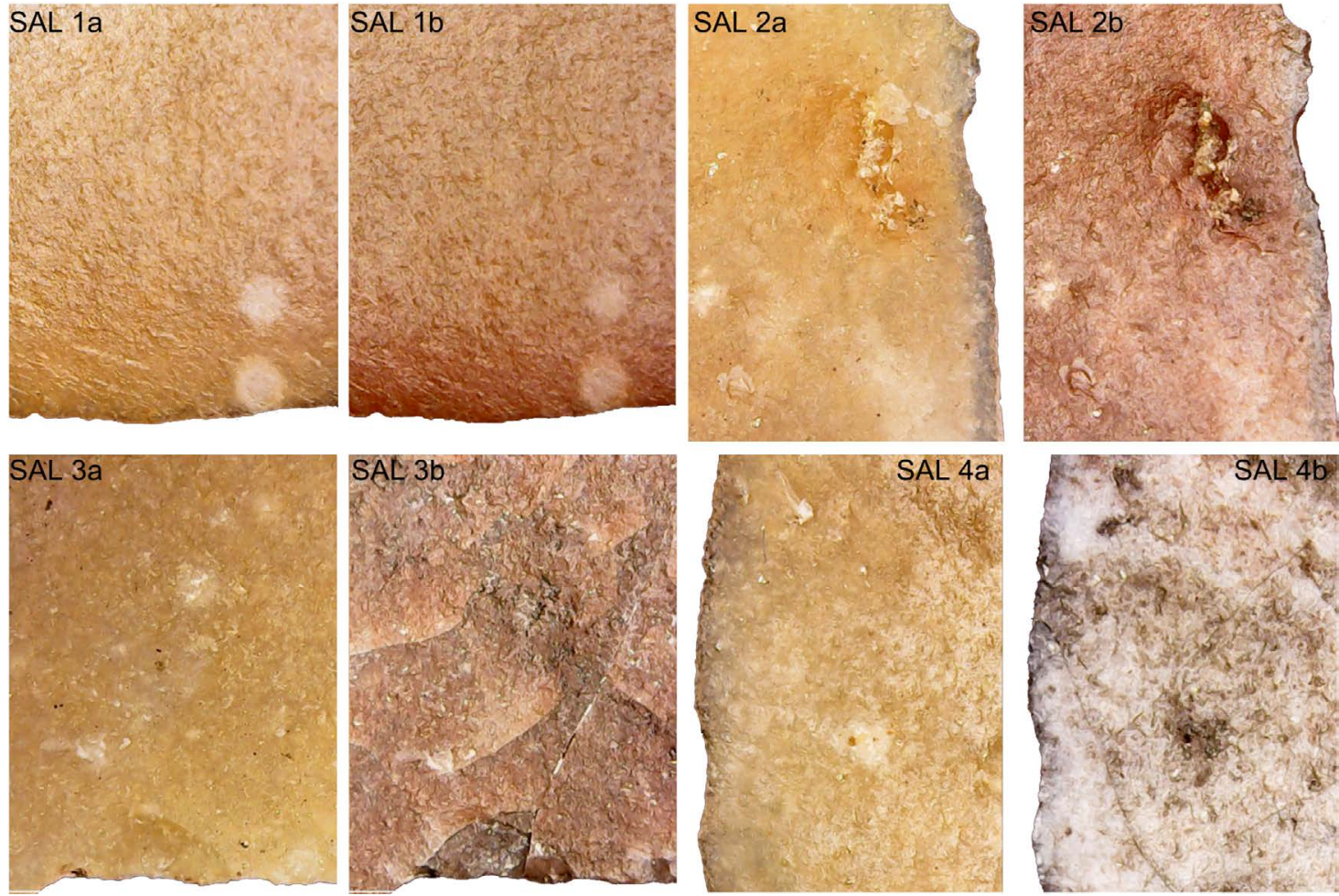

Figure 5. Described Surface Alteration Levels (SAL) for samples of Bergerac flint. SAL 1a and 1b where dehydration is almost absent and the developed color is associated with the original; SAL 2a and $2 \mathrm{~b}$ with a higher development of dehydration, higher topographic visibility, and development of the characteristic waxy luster; SAL 3a and 3b where surface has been blackened because of carbonization; SAL 4a and 4b where surface presents extreme dehydration associated with color white of incineration.
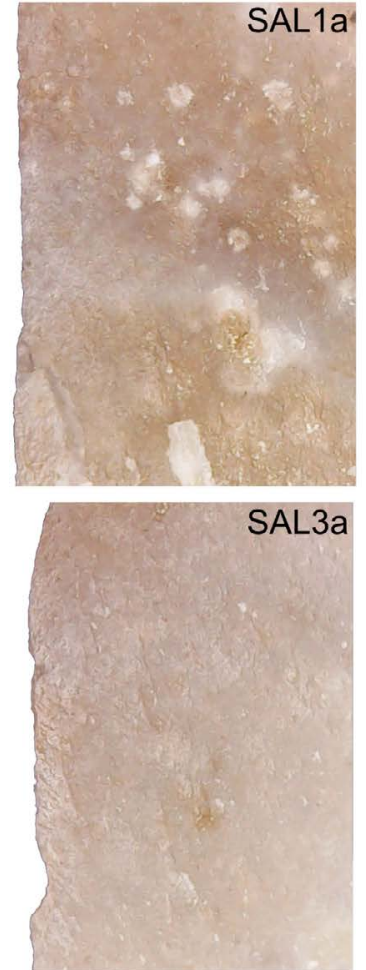
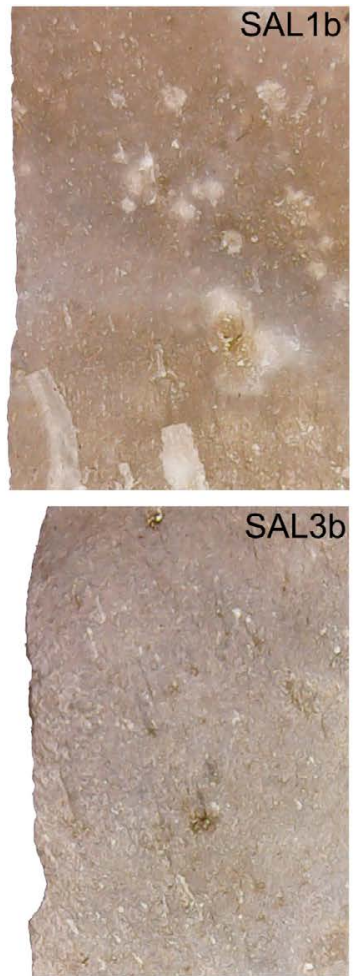
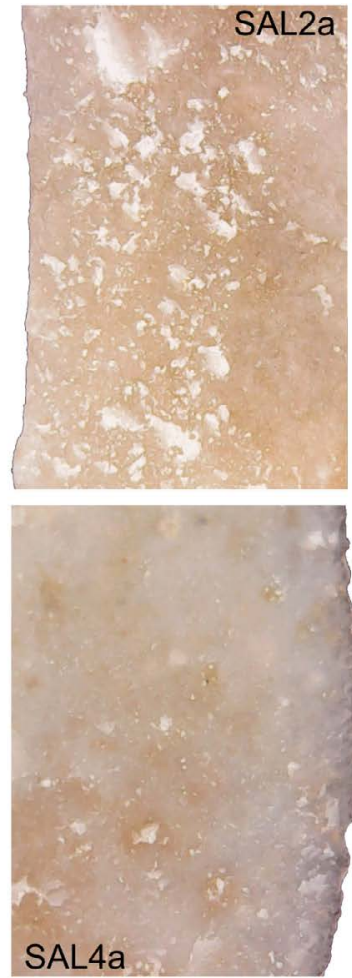
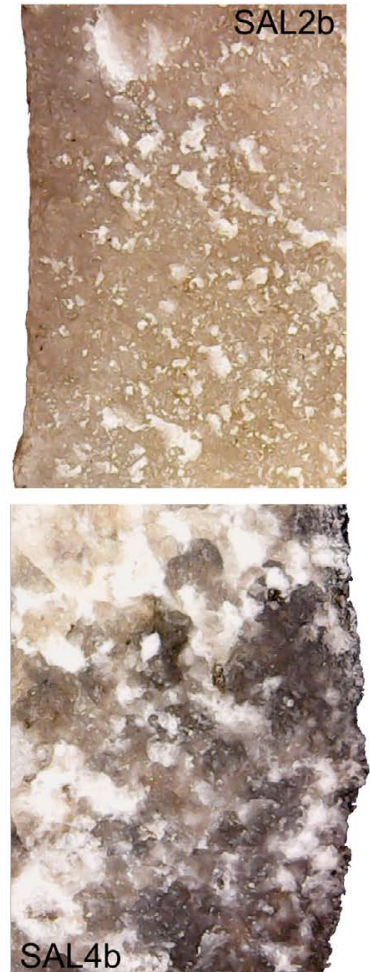

Figure 6. Described Surface Alteration Levels (SAL) for SMM flint. SAL 1a and 1b where dehydration is almost absent and the developed color is almost absent; SAL 2a and 2b with a higher development of dehydration, higher topographic visibility, and development of the characteristic waxy luster; SAL 3a and 3b where surface has been blackened because of carbonization; SAL 4a and 4b where surface presents a spongy surface due to extreme dehydration and associated with color white of incineration. 


\section{Results}

Figure 7 shows thermal curves of hearths 1, 2 and 3. Maximum temperature peak for the surface ranged between $840{ }^{\circ} \mathrm{C}$ for hearth 2 and $800{ }^{\circ} \mathrm{C}$ for hearth 1 and 3 and after four hours temperature had dropped below $400{ }^{\circ} \mathrm{C}$. Temperature estimations for layers under the surface were done according to March et al., (1993; 2014) and Carrington (2009). Although it would have been interesting and provided additional data to use buried probes to measure the temperature at the buried depths, this was not possible at present. At the current stage of this research, the main objective was to acquire preliminary experimental data on the general effect of depth on the thermal alterations. The temperature of the surface was sufficient to indicate this. It is important though for future research to measure also the temperature in each layer.

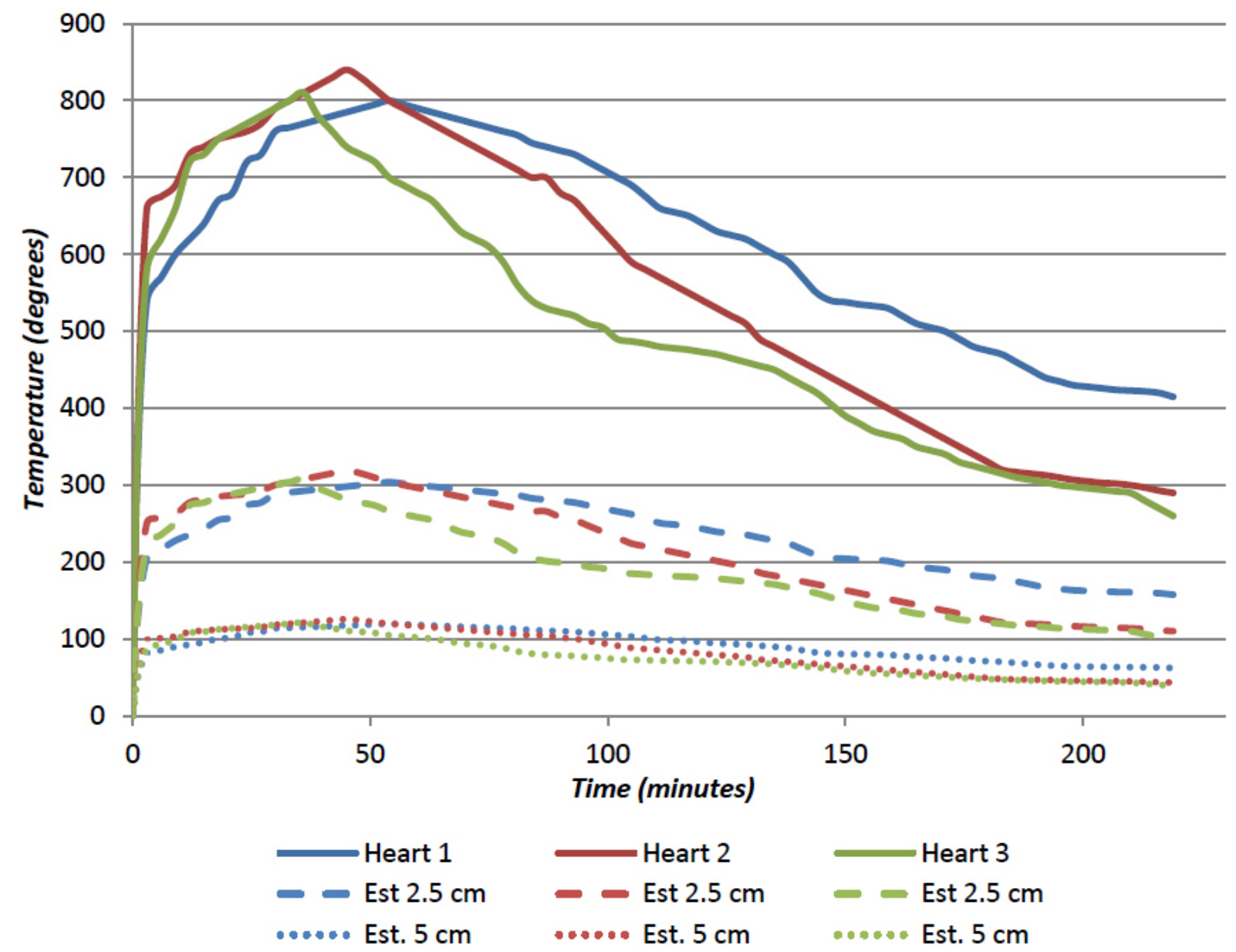

Figure 7. Evolution of surface temperature for each of the experimental set-ups and estimation of layer temperature. Hearth 1 (69 blanks of Bergerac flint) and hearth 2 (70 blanks of SMM flint) where employed to test differential heat impact among lithic artifacts. Hearth 3 was designed to test direct throwing of flint blanks and recycling after re-burning.

\subsection{Results: differential heat impact from a vertical point of view}

Figure 8 presents the table of presence or absence of thermal alterations and SAL for each layer and for both flints analyzed, considering layer assemblage as a hole. First impression calls for the differences between both flints in the level of fracturing and development of heat alterations. While samples of Bergerac flint are easily broken by heat impact and they also develop heat alterations in an easier way (both in layers 1 and 2), samples of SMM flint are hardly broken and do not tend to develop heat alterations such as 
thermal bubbles or internal cracking. As an example, Bergerac flint blanks from layer 1 present transversal fractures $(20 \% n=5)$ and marginal fractures $(24 \% n=6)$, while SMM blanks from layer 1 also present these fractures, but in a lower frequency $(9 \% n=2 ; 9 \% n=2$ respectively). In layer 2 frequency of fractures in samples of Bergerac flint diminishes with presence of longitudinal fractures $(8 \% n=2)$, transversal fractures $(4 \% ; n=1)$ and marginal fractures $(12 \% n=3)$, and fractures are absent in SMM flint blanks from layer 2 .
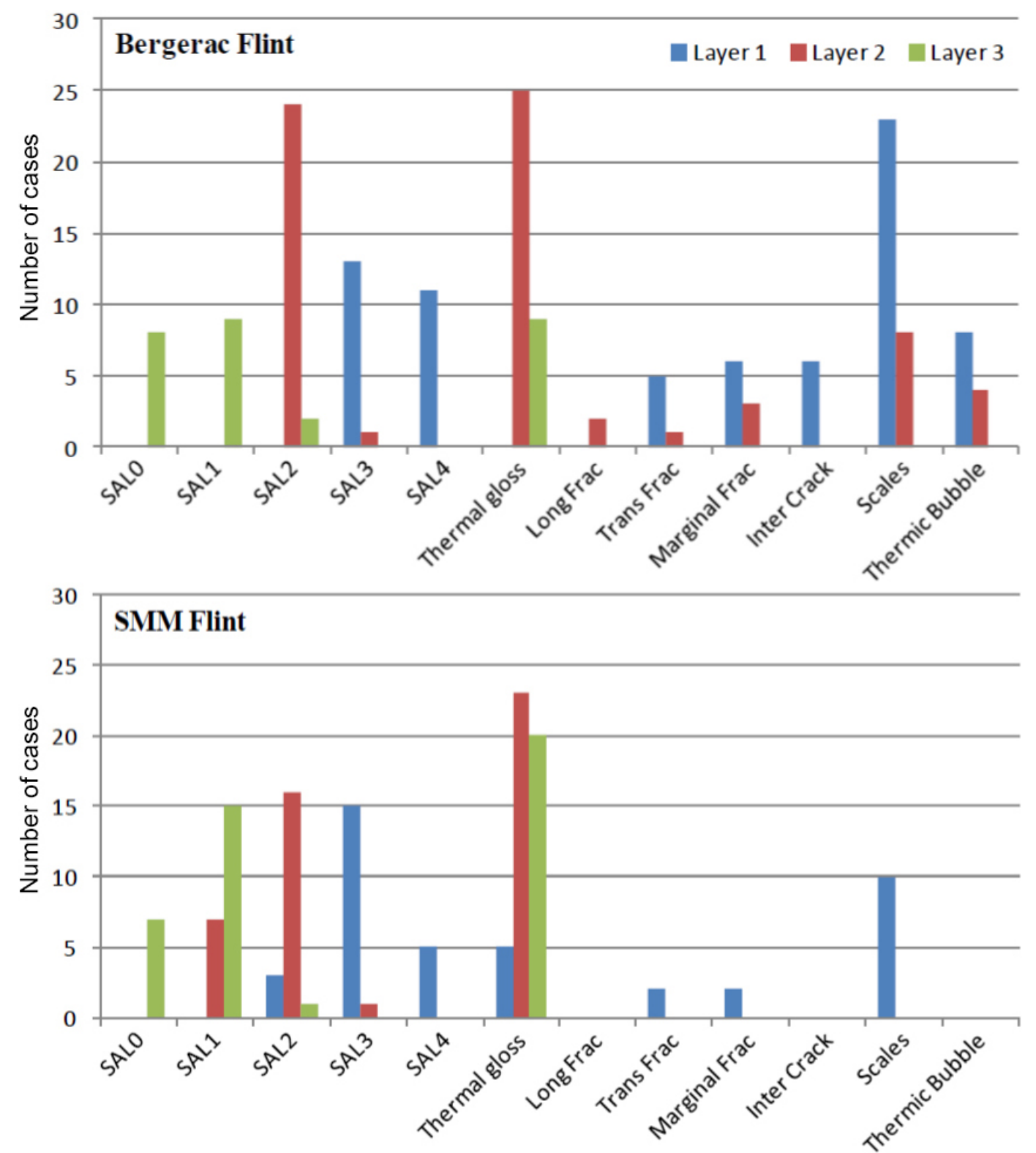

Figure 8. Presence or absence table of occurrence of cases for SAL and heat alteration features according to layer distribution

As mentioned, Bergerac flint blanks also present higher frequencies of thermal alterations. In layer 1 there is very high presence of scales $(92 \% n=23)$, and internal cracking $(24 \% \mathrm{n}=6)$ and thermal bubbles $(32 \% \mathrm{n}=8)$ are also present. In layer 2 the absolute frequency diminishes ( $n=8 / 25$ of scales; $n=4 / 25$ of thermal bubbles and absence of internal cracking). The only heat alteration documented for SMM flint is the presence of scales and only in samples from layer $1(43 \%$; $n=10)$ which were in surface contact with fire. Other differences that can be observed are the effects of direct surface impact among blanks from 
the first layer. The characteristic waxy thermal luster is absent in Bergerac flint blanks coming from layer 1 . This is due to the high development of SAL $3(52 \% n=13)$ or SAL 4 $(48 \% \mathrm{n}=12)$ in all of the blanks from layer 1 , resulting in extreme levels of incineration or carbonization (example on figure 11a). In the other hand, thermal gloss is present SMM flint blanks coming from layer 1 . This can be related with a lower development of SAL $4(22 \% n=$ 5) since SMM flint blanks from this level tend to present SAL $3(65 \% n=15)$. A common factor observed is that the development of scales is the most common heat alteration developed by both samples of raw materials, but in the case of SMM flint this feature only develops in blanks from layer $1(43 \%$; $n=10)$, while this is a common feature for blanks coming from layers $1(92 \% n=23)$ and $2(32 \% n=8)$ in the case of Bergerac flint.
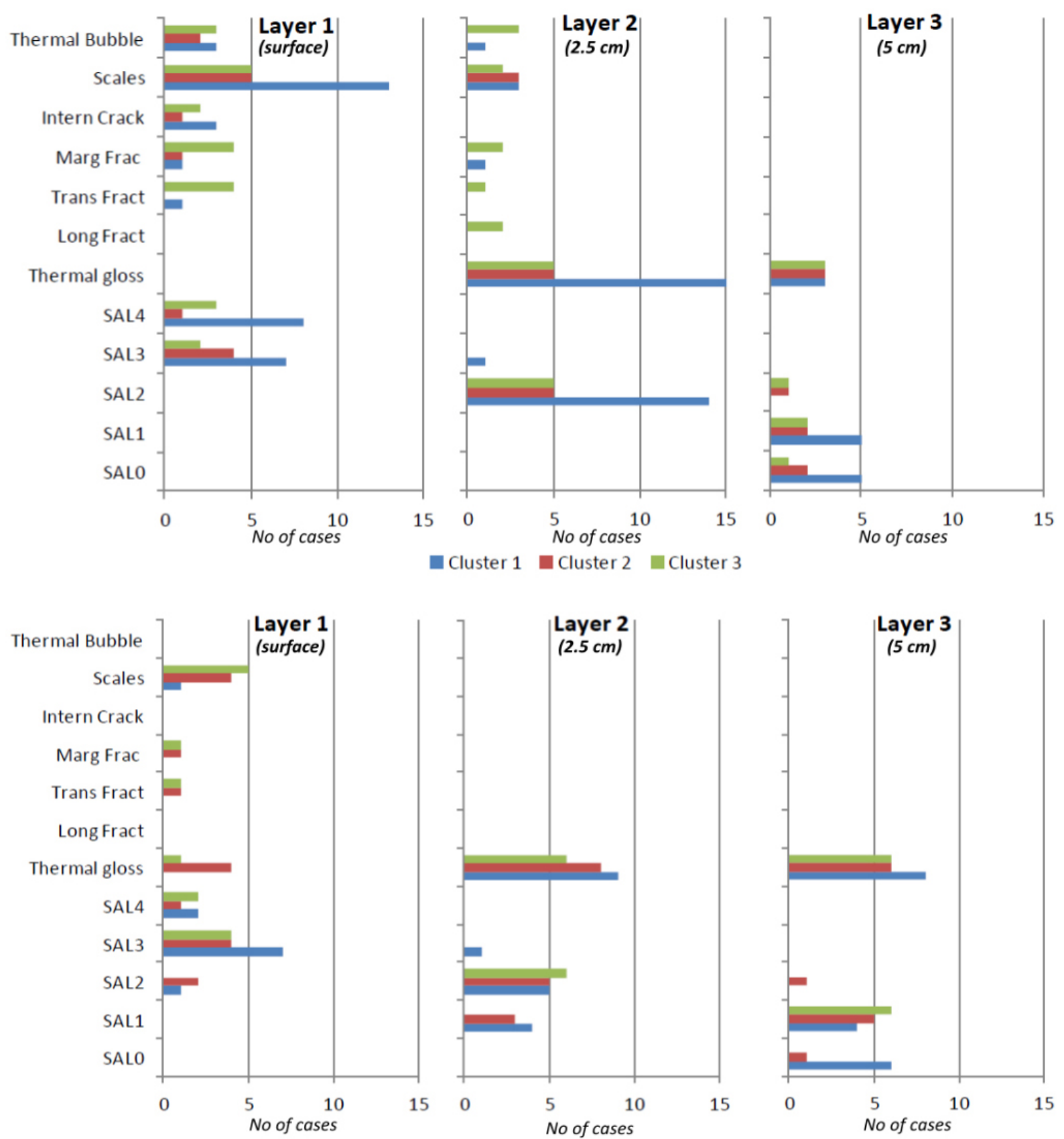

Figure 9. Presence or absence case table of SAL and heat alteration features for Bergerac flint blanks (above) SMM flint blanks (below). Results are shown according to volume cluster for each of the layers (note that cluster 3 also includes cluster 4). 

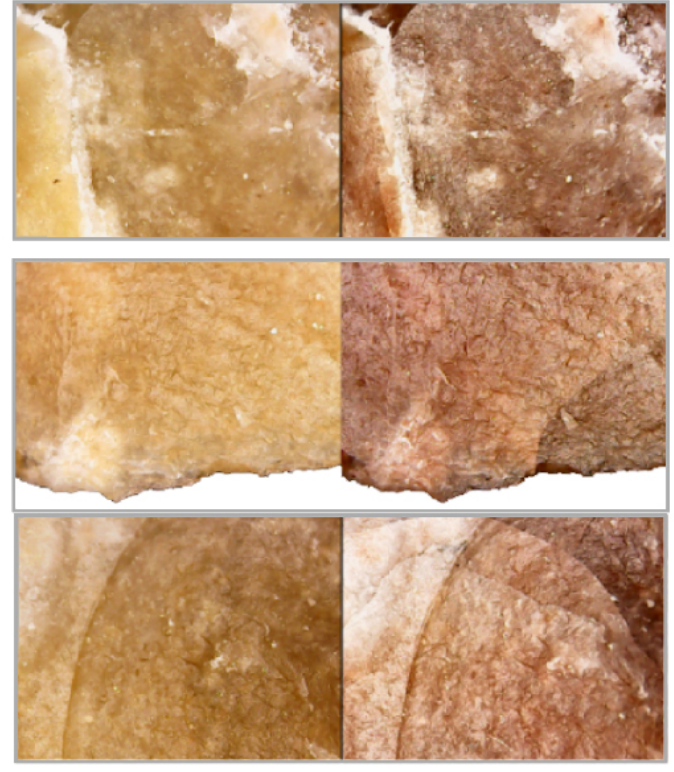

a
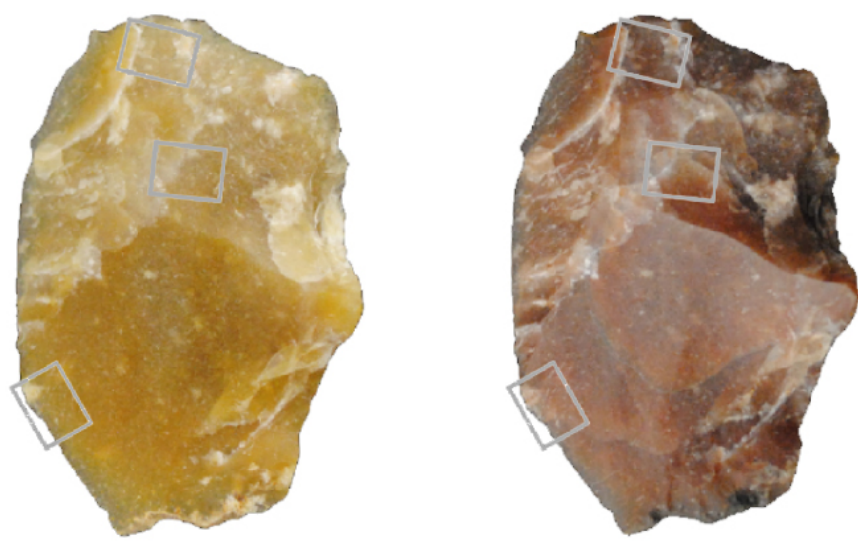

0

$5 \mathrm{~cm}$
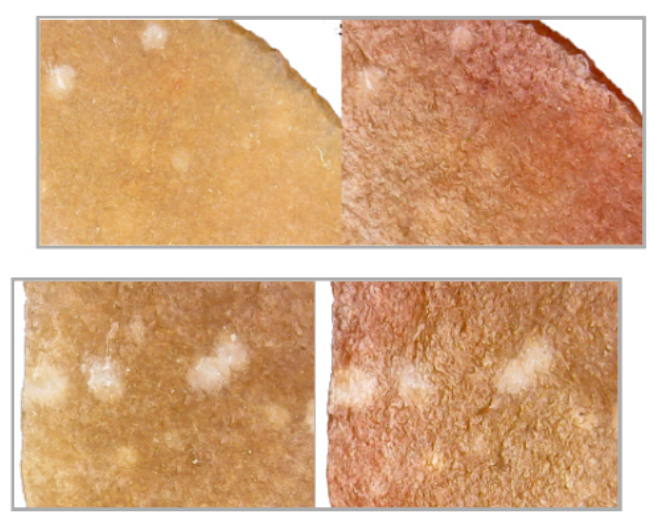

b

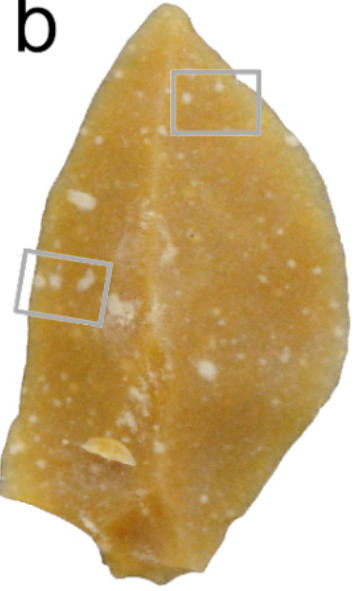

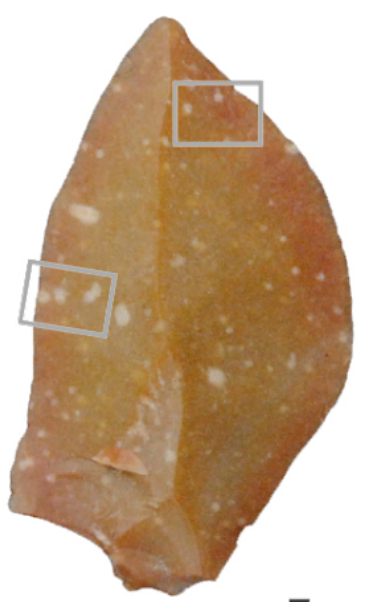

0

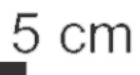

Figure 10. Macro and detail photos of Bergerac blanks located a) $2.5 \mathrm{~cm}$ and b) $5 \mathrm{~cm}$ below the hearth; a) presents SAL2 showing the development of the characteristic waxy luster and presence of scales (second and bottom detail photos); b) blank that presents SAL1 with characteristic waxy luster, lower level of dehydration and original color associated to developed color.

When blanks were analyzed according to layer and cluster volume (Figure 9), a correlation between blank volume and heat alterations can be observed. In the case of Bergerac flint, this correlation isn't very good between blank volume and the development scales since they are developed in a general way, being present in all blanks of cluster 2 and 3 , and in $87 \%$ of blanks from cluster $1(n=13)$, although it is important to remind that scales are the most common heat alteration. Thermal bubbles tend to be present in higher volumetric blanks ( $20 \% \mathrm{n}=3$ for cluster $1 ; 40 \% \mathrm{n}=2$ for cluster 2 and $60 \% \mathrm{n}=3$ for cluster 3 ). Degree of breakage is higher in blanks of higher volume ( $80 \% n=4$ for cluster 3$)$, with marginal fractures being the most common ones. All blanks present SAL3 or SAL4, independent of their volume. In the case of layer 2 thermal alterations are constrained to blanks of higher volume. Frequency of scales is reduced from $87 \%(n=13)$ to $20 \%(n=3)$ on blanks of cluster 1 , while this reduction is not so drastic in the case of higher volume blanks. Frequency of thermal bubbles and fractures is higher in volume cluster 3, and most of blanks present SAL2 with a well development of the characteristic waxy thermal gloss (Figure 10a). In layer 3, the 
only thermal alteration is the presence of SAL1 (although blanks of higher volume might develop SAL2) along with presence of thermal gloss (example on Figure 10b)
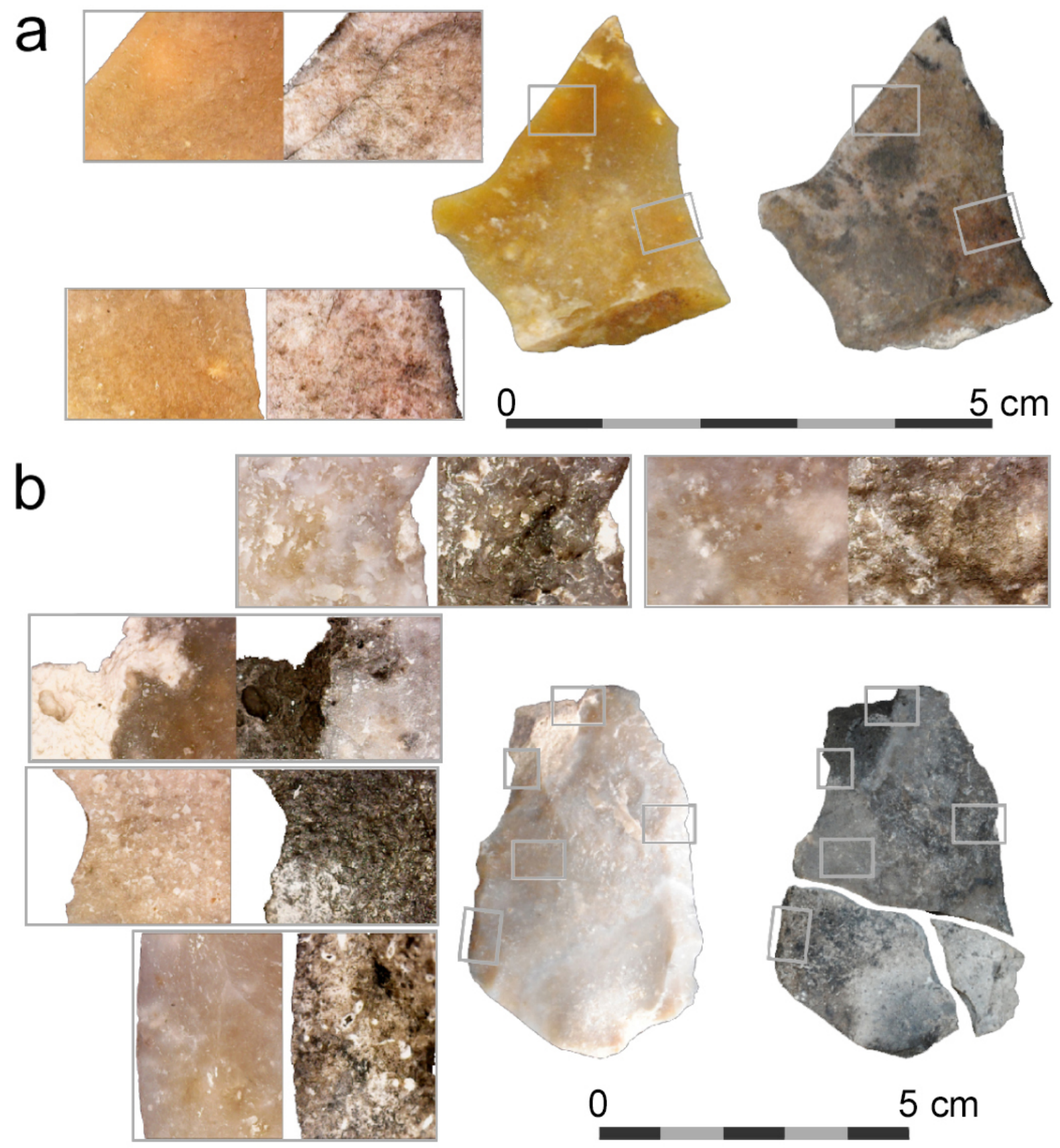

Figure 11. Macro and detail photos of blanks altered by surface contact with fire. a) Small Bergerac flint blank presenting SAL 4 and development of internal cracking; b) SMM flint blank presenting SAL 4 and marginal and transversal fractures. In the case of SMM blank cortex and sandy surface tend to be carbonized while more siliceous flint-like surface tends to high dehydration, presenting SAL4.

In the case of SMM flint blanks correlation between blank volume and development of heat alterations seems to be clearer (Figure 9) since blanks of higher volume are the ones that present higher number of alterations (although it is important to take in consideration that SMM is hardly altered). This correlation can also be observed for the presence of scales that are more common on blanks of higher volume $(83 \% n=5)$ than in blanks of lower volume $(10 \% \mathrm{n}=1)$. Breakage is absent in blanks of lower volume, while degree of breakage (figure 11b) is low for cluster 1 and 2 blanks and most of the blanks present SAL3, independent of 
volume (70\% $n=7$ for cluster $1 ; 57 \% n=4$ for cluster $2 ; 66 \% n=4$ for cluster 3$)$. For layers 2 and 3 there is an absence of thermal alterations, although higher volume blanks are grouped in SAL2 for layer 2 and SAL1 for layer 3. In layer 3 blanks of lower volume usually present SAL0.

\subsection{Results: blanks thrown directly into the hearths and recycled blanks}

Along with blanks used to test differential heat impact from a vertical point of view a sample was employed to test the effects of throwing blanks directly over ashes. Sample was composed of 10 Bergerac blanks and 9 SMM blanks. Figure 12a presents volume of blanks thrown directly over the ashes when maximum surface temperature had dropped to $\sim 600{ }^{\circ} \mathrm{C}$ (Bergerac blanks were thrown over surface of hearth 2 and SMM blanks were thrown over the surface of hearth 3).
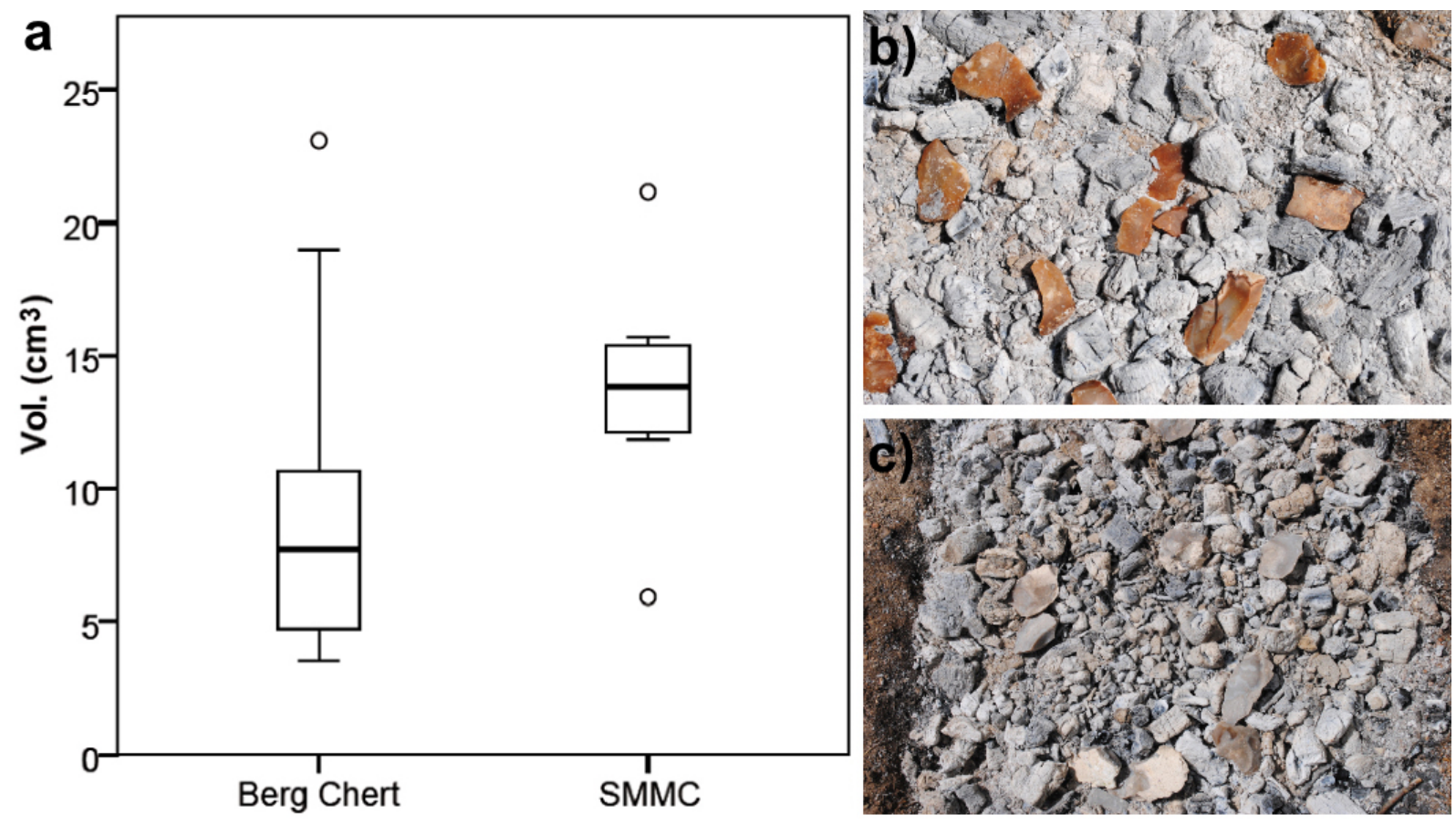

Figure 12. a) Box plots showing volume of blanks employed to test effects of throwing blanks directly to the hearths; b) experiment undertaken for Bergerac flint blanks and c) experiment undertaken for SMM flint blanks.

Results of presence or absence of SAL and heat alterations (Figure 13) show that all blanks of both types of flints tend to develop SAL2 along with an intense thermal gloss, and absence of carbonization (SAL3), incineration (SAL4) or development of thermal bubbles (pattern that differs from blanks of layer 1 and 2). Again development of heat alterations differs between flints, being absent in SMM flint and presenting differential development in Bergerac blanks. For Bergerac blanks scales are the most common heat alteration, being present in four of ten blanks while samples also show a moderate presence of internal cracking $(n=4)$ and diverse types of fractures $(n=1$ for longitudinal and transversal fractures, and $n=3$ in the case of marginal fractures). SMM flint blanks do not present any kind of heat alteration except a clear development of an intense thermal luster.

For the development of the recycling experiment, a limited sample of blanks that had gone through heat impact in previous experiments was selected (9 blanks from Bergerac flint and 7 from SMM flint). All recycling episodes were carried out though direct retouch, blanks were photograph macroscopically and in detail (allowing to capture recycled and nonrecycled surfaces) and blanks were laid in layer 2 (this is $2.5 \mathrm{~cm}$ below surface) of hearth 3 . 
When recovered, it was possible to distinguish recycled surfaces (Figure 14 as an example) in all cases of both raw materials (both surfaces change, but at a different rhythm).

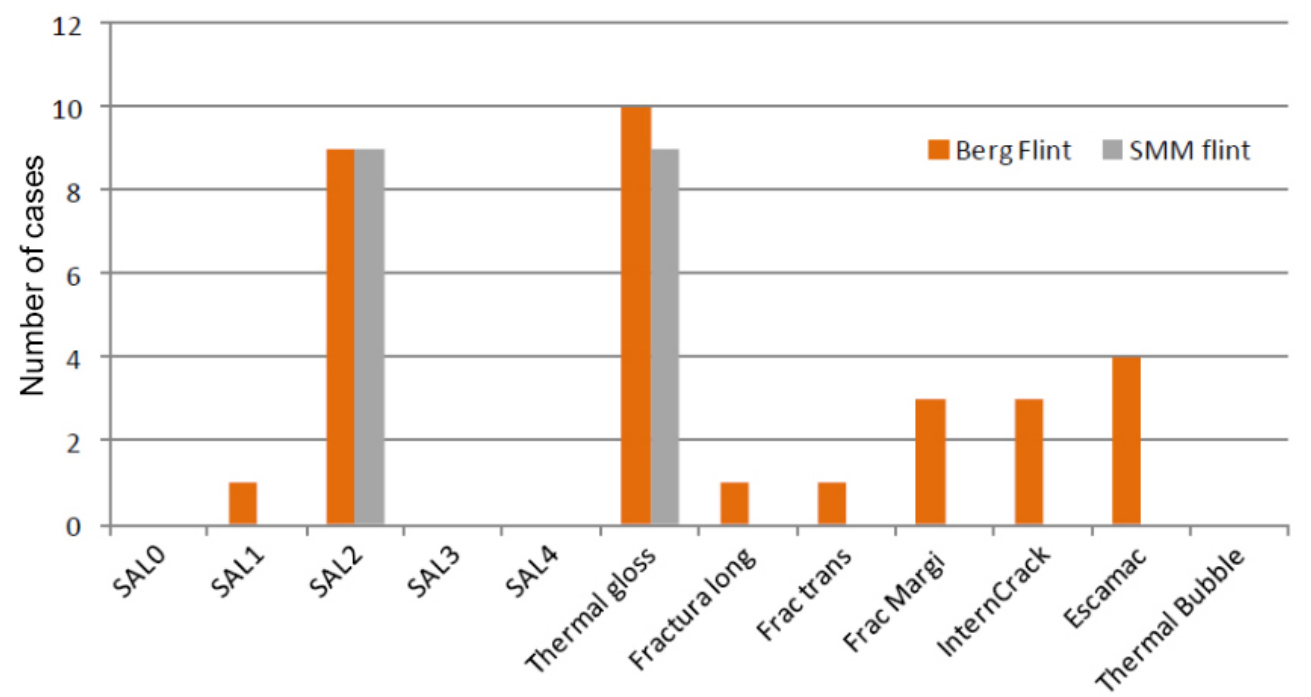

Figure 13. Presence or absence absolute table of SAL and heat alteration features for Bergerac and SMM flint blanks thrown over de ashes of the hearth when temperature had dropped to $\sim 600{ }^{\circ} \mathrm{C}$.
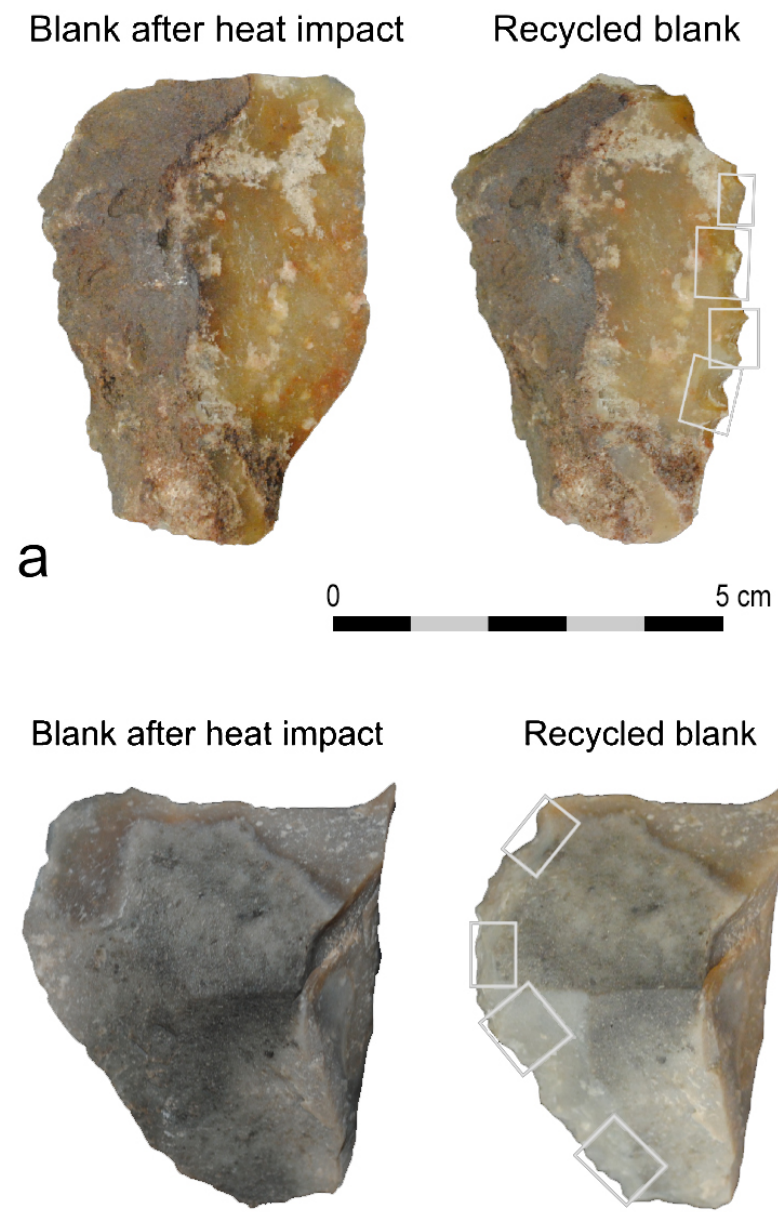

b

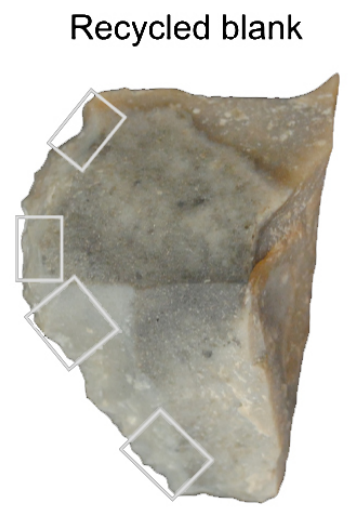

0

Figure 14. Macroscopic and detail photos of a) Bergerac and b) SMM flint blanks that went under heat impact, were recycled and went through heat impact again. In all cases it was possible to distinguish recycled surfaces through retouch from non-recycled surfaces
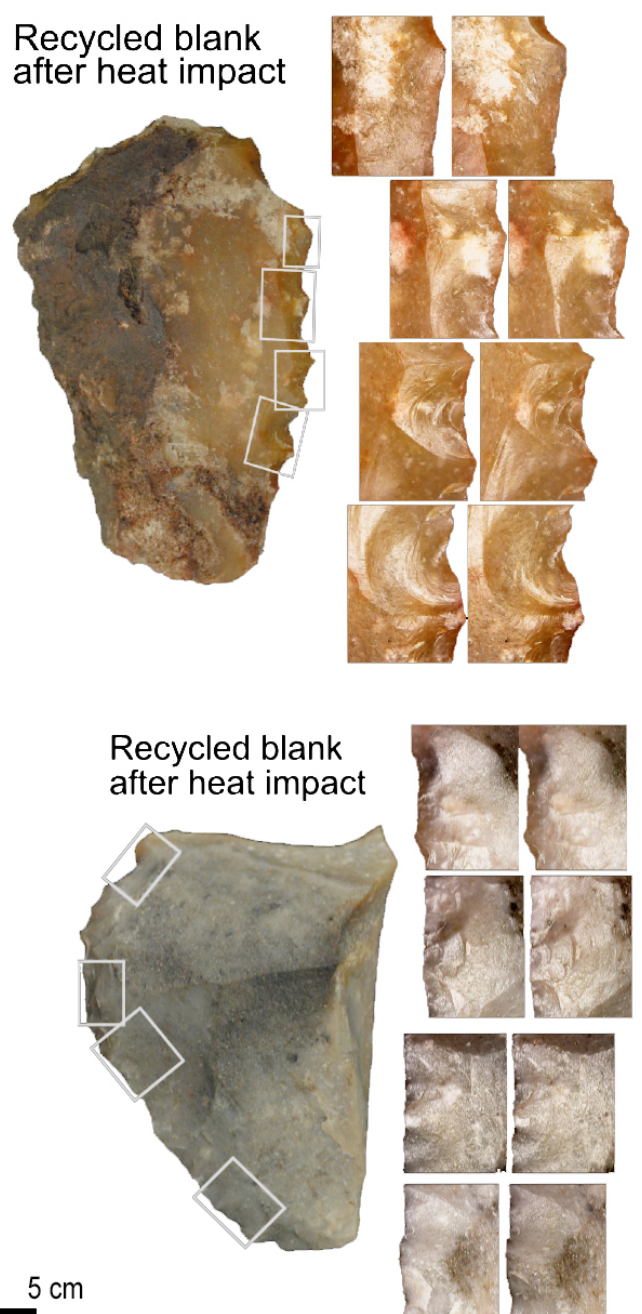


\section{Discussion}

Results of the experimental study support the hypothesis that volume is a key factor for the understanding of heat fractures and also for the understanding of the development of heat alterations. This study has also presented SAL as a useful integrative system to classify heat altered surfaces on flint blanks and a better understanding of post-depositional processes and effects. This study also provides results on the frequency of development of SAL and heat alterations and the circumstances under they might occur (example: scales are the most common heat alteration under all types of heat impact; while thermal bubbles are not present in blanks directly thrown to hearths). Finally, results have also reinforced previous observations were cracking or fracture will differ between different siliceous rock (this is also applicable to the development of heat alterations). Comparative patterns of heat alterations and fracture degrees for both types of raw materials can be observed in Tables 1 and 2.

This study provides additional results on development and frequency of heat alterations taking as condition the different levels of heat exposure under a hearth, and it also provides a clear example of how different raw materials might react to heat exposure. We also consider that the combination of SAL, blank volume and presence or absence of heat alterations can help identify types of heat exposure on the field (although individual studies for each raw material should be carried out).

Table 1. Observed comparative patterns of development of heat alterations (Bergerac flint blanks). Abbreviations: + - low presence or low development of feature; ++ - feature commonly present; +++ - feature present in all cases and highly developed; blank cells indicate absence of feature; Dire $\mathrm{T}$ - blanks thrown directly.

\begin{tabular}{|c|c|c|c|c|c|c|c|c|c|c|}
\hline & SALO & SAL1 & SAL2 & SAL3 & SAL4 & $\begin{array}{c}\text { Thermal } \\
\text { gloss }\end{array}$ & $\begin{array}{c}\text { Fract } \\
\text { degree }\end{array}$ & $\begin{array}{c}\text { Intern } \\
\text { crack }\end{array}$ & Scales & $\begin{array}{c}\text { Thermal } \\
\text { Bubb }\end{array}$ \\
\hline L1 & & & & +++ & +++ & + & +++ & ++ & +++ & ++ \\
\hline L2 & & & +++ & + & & +++ & ++ & & ++ & ++ \\
\hline L3 & ++ & ++ & & & & ++ & & & & \\
\hline Dire T & & & +++ & & & +++ & ++ & ++ & ++ & \\
\hline
\end{tabular}

Table 2. Observed comparative patterns of development of heat alterations (SMM flint blanks). Abbreviations: + - low presence or low development of feature; ++ - feature commonly present; +++ - feature present in all cases and highly developed; blank cells indicate absence of feature; Dire T - blanks thrown directly.

\begin{tabular}{lcccccccccc}
\hline & \multicolumn{1}{c}{ SAL0 } & SAL1 & SAL2 & SAL3 & SAL4 & gloss & degree & crack & Scales & Bubb \\
\hline L1 & & & & +++ & ++ & + & ++ & & ++ & \\
L2 & & ++ & +++ & + & & ++ & & & & \\
L3 & +++ & ++ & & & & + & & & \\
Dire T & & & +++ & & & +++ & & & & \\
\hline
\end{tabular}

Mercierca (2000) and Mercierca \& Hiscock (2008) state that volume is one of the principal variables that influence fractures and cracking caused by heat impact. Schimdt et al., (2012) explain that as higher is the volume of an artifact, longer is the distance that water must cover for evacuating from the center of the blank, contributing to vapor pressure and eventual fracture. As mentioned before, the results of this study support this hypothesis and allow to state that volume is also a major variable affecting the development of SAL and heat 
alterations. Despite studies that directly focus on frequency of heat alterations are not common, some examples can be found. Frick et al., (2012) results show similar trends in the development of heat alterations on flint from Côtte Chalonnaise, with scales being the most common heat alteration observed.

Schmidt's et al., (2012) model for heat treatment can help understand variables related with the development of heat alterations. Under uncontrolled conditions of heat exposure maximal temperature for heat treatment is clearly over passed in a short time (especially at upper layers) and water doesn't have enough time to evacuate from the inner parts of the blank. Also long term duration of hearths and high temperatures result in blanks not having enough time to rehydrate. This can be a direct cause for the presence of scales, thermal bubbles, different types of fractures, and blank disintegration. Schmidt et al. (2012) also point that different temperatures between outside and inside of the blank can lead to heterogeneous dilatation and thus to internal cracking. This can be an explication of why internal cracking is not a common heat alteration for blanks laying under the surface of a hearth, but it is present in artifacts directly thrown or in upper layers, and in artifacts of higher volume.

Results presented here constitute a first stage of a wider study focused on the development of heat alterations on lithic materials. Further research is aimed to expand number of blanks submitted to heat impact (hence allowing for more robust statistical evidence); increase number of raw materials involved in the study; and undertake petrological studies that will allow testing the effects of porosity and geochemical composition on the development of heat alterations.

\section{Conclusions}

Identifying levels of heat alteration in flint blanks is not an easy task, especially when they are undertaken on the field. Here a new method to classify heat alterations on lithic artifacts (surface alteration levels, $S A L$ ) is presented, along with evidence that relates heat exposure with development of SAL and heat alterations. We hope that results presented here add evidence and help for a greater global understanding of the effects different kinds of heat exposure to the development of heat alterations.

\section{Acknowledgements}

This article was presented in the $10^{\text {th }}$ International Symposium of Knappable Materials, 'On the Rocks' (University of Barcelona, 7-12 of September 2015). The authors would like to thank all those who have participated and continue to participate in this work, and in particular to: Nuria Castañeda, Concepción Torres, Maria Gema Chacón Navarro, and all the members of the LAEX UAM (Laboratorio de Arqueología Experimental UAM), for their support and advice. We are also thankful to reviewers for their time and suggestions. This contribution is a part of the research project HAR2013-48784-C3-3-P ¿Cómo, Quíen y Dónde?: Variabilidad de Comportamientos en la Captacion y Transformacion de los Recursos Líticos Dentro de Grupos Neandertales financed by the Ministerio de Economía y Competitividad of Spain.

\section{References}

Aldeias, V., Goldberg, P., Sandgathe, D., Berna, F., Dibble, H.L., McPherron, S.P., Turq, A. \& Rezek, Z. 2012, Evidence for Neandertal use of fire at Roc de Marsal (France). Journal of Archaeological Science, 39: 2414-2423. doi:10.1016/j.jas.2012.01.039 
Blasco, R., Rosell, J., Gopher, A. \& Barkai, R. 2014, Subsistence economy and social life: A zooarchaeological view from the 300 kya central hearthh at Qesem Cave, Israel. Journal of Anthropological Archaeology, 35: 248-268. doi:10.1016/j.jaa.2014.06.005

Borradaile, G.J., Kissin, S.A., Stewart, J.D., Ross, W.A. \& Werner, T. 1993, Magnetic and optical methods for detecting the heat treatment of chert. Journal of Archaeological Science, 1993: 57-66. doi:10.1006/jasc.1993.1004

Bustillo, M.A. \& Pérez-Jiménez, J.L. 2005, Características diferenciales y génesis de los niveles silíceos explotados en el yacimiento arqueológico de Casa Montero (Vicálvaro, Madrid). Geogaceta, 38: 243-246. (in Spanish) ("Differential features and genesis of silica levels mined in the Casa Montero archaeological site. (Vicálvaro, Madrid)"). URL: http://hdl.handle.net/10272/8693

Carrington, M.E. 2010, Effects of Soil Temperature during Fire on Seed Survival in Florida Sand Pine Scrub. International Journal of Forestry Research, 2010: 10p. doi:10.1155/2010/402346

Clemente-Conte, I. 1995, Sílex y lustre térmico en el Paleolítico Medio. ¿Alteración o técnica de talla? El ejemplo de Mediona I (Alt Penedès, Barcelona). Trabalhos de Antropologia e Etnologia, 35(3): 37-43. (in Spanish) (Flint and thermal gloss at the Middle Paleolithic. Thermal alteration or knapping technique? The example of Mediona I (Alt Penedès, Barcelona) URL: http://hdl.handle.net/10261/47869

Clemente-Conte, I. 1997, Thermal Alterations of Flint Implements and the Conservation of Microwear Polish: Preliminary Experimental Observations. In: Siliceous Rocks and Culture, (Ramos Millan, A. \& Bustillo, M.A., Eds.), Universidad de Granada, Granada: p. 525-535.

Crabtree, D.E. \& Butler, B.R. 1964, Notes on Experiment in Flint Knapping: 1 Heat Treatment of Silica Materials. Tebiwa, 7: 1-6.

Dorta, R., Hernández, C., Molina, F. \& Galván Santos, B. 2010, La alteración térmica en los sílex de los valles alcoyanos (Alicante, España). Una aproximación desde la arqueología experimental en contextos del Paleolítico Medio: El Salt. Recerques del Museu d'Alcoi, 19: 33-64. (in Spanish) ("The thermal alteration in the Alcoyan flint (Alcoy, Alicante, Spain). An approach from the experimental archaeology in Middle Palaeolithic contexts: El Salt of Alcoy URL: http://www.raco.cat/index.php/RecerquesMuseuAlcoi/article/view/197124

Fernandes, P. \& Raynal, J.-P. 2006, Pétroarchéologie du silex: un retour aux sources. Compets Rendus Palevol, 5: 829-837. (in French) ("Petroarchaeology of flint artefacts a return to the source") doi:10.1016/j.crpv.2006.04.002

Fernández Peris, J., Barciela González, V., Blasco, R., Cuartero, F., Fluck, H., Sañudo, P. \& Verdasco, C. 2012, The earliest evidence of hearthhs in Southern Europe: The case of Bolomor Cave (Valencia, Spain). Quaternary International, 247: 267-277. doi:10.1016/j.quaint.2010.10.014

Frick, J.A., Hoyer, C.T., Herkert, K. \& Floss, H. 2012, Comparative heating experiments on flint from the Côte Chalonnaise, Burgundy, France. Anthropologie, 3: 295-321. URL: http://puvodni.mzm.cz/Anthropologie/article.php?ID=1487

Fukuda, J. \& Nakashima, S. 2008, Water at high temperatures in a microcrystalline silica (chalcedony) by in-situ infrared spectroscopy: physicochemical states and dehydration 
behavior. Journal of Mineralogical and Petrological Sciences, 103: 112-115. doi:10.2465/jmps.071022a

Goldberg, P., Dibble, H.L., Berna, F., Sandgathe, D., McPherron, S.J.P. \& Turq, A. 2012, New evidence on Neandertal use of fire: Examples from Roc de Marsal and Pech de l'Aze IV. Quaternary International, 247: 325-340. doi:10.1016/j.quaint.2010.11.015

Henry, D. 2012, The palimpsest problem, hearthh pattern analysis, and Middle Paleolithic site structure. Quaternary International, 247: 246-266. doi:10.1016/j.quaint.2010.10.013

Hiscock, P. 2002, Quantifying the Size of Artefact Assemblages. Journal of Archaeological Science, 29: 251-258. doi:10.1006/jasc.2001.0705

Inizan, M.-L., Reduron-Ballinger, M., Roche, H. \& Tixier, J. 1995, Technologie de la pierre taillée. Vol. 4. Préhistoire de la Pierre Taillée. Cercle de Recherches et d'Etudes Préhistoriques (C.R.E.P.), Meudon, 199 p.

Karkanas, P., Shahack-Gross, R., Ayalon, A., Bar-Matthews, M., Barkai, R., Frumkin, A., Gopher, A. \& Stiner, M.C. 2007, Evidence for habitual use of fire at the end of the Lower Paleolithic: Site-formation processes at Qesem Cave, Israel. Journal of Human Evolution, 53: 197-212. doi:10.1016/j.jhevol.2007.04.002

Mallol, C., Hernández, C.M., Cabanes, D., Sistiaga, A., Machado, J., Rodríguez, Á., Pérez, L. \& Galván, B. 2013, The black layer of Middle Palaeolithic combustion structures. Interpretation and archaeostratigraphic implications. Journal of Archaeological Science, 40: 2515-2537. doi:10.1016/j.jas.2012.09.017

March, R.J., Ferreri, J.C. \& Guez, C. 1993, Étude des foyers préhistoriques des gisements magdaléniens du Bassin Parisien. Mémoires du Groupement Archéologique de Seine-etMarne, 1: 87-95.

March, R.J., Lucquin, A., Joly, D., Ferreri, J.C. \& Muhieddine, M. 2014, Processes of Formation and Alteration of Archaeological Fire Structures: Complexity Viewed in the Light of Experimental Approaches. Journal of Archaeological Method and Theory, 21: 1-45. doi:10.1007/s10816-012-9134-7

Mercierca, A. 2000, Burnt and broken: An experimental study of heat fracturing in silcrete. Australian Archaeology, 51: 40-47. doi:10.1080/03122417.2000.11681679

Mercierca, A. \& Hiscock, P. 2008, Experimental insights into alternative strategies of lithic heat treatment. Journal of Archaeological Science, 35: 2634-2639. doi:10.1016/j.jas.2008.04.021

Ortiz Nieto-Márquez, I. \& Baena Preysler, J. 2015, Experiments around the fire. Discovering human and natural processes in Middle Paleolithic Hearths. Anthropologie, 53(3): 501518. URL: http://puvodni.mzm.cz/Anthropologie/article.php?ID=2155

Patterson, L. 1995, Thermal damage of chert. Lithic Technology, 20(1): 72-80. URL: http://www.jstor.org/stable/23273161

Schmidt, P., Masse, S., Laurent, G., Slodczyk, A., Le Bourhis, E., Perrenoud, C., Livage, J. \& Fröhlich, F. 2012, Crystallographic and structural transformations of sedimentary chalcedony in flint upon heat treatment. Journal of Archaeological Science, 39: 135144. doi:10.1016/j.jas.2011.09.012

Shea, J.J. 2003, The Middle Paleolithic of the East Mediterranean Levant. Journal of World Prehistory, 17(4): 313-394. doi:10.1023/B:JOWO.0000020194.01496.fe 
Simek, J. 1984, Integrating Pattern and Context in Spatial Archaeology. Journal of Archaeological Science, 11: 405-420. doi:10.1016/0305-4403(84)90021-9

Vaquero, M. \& Pastó, I. 2001, The Definition of Spatial Units in Middle Palaeolithic Sites: The Hearthh-Related Assemblages. Journal of Archaeological Science, 28: 1209-1220. doi:10.1006/jasc.2001.0656

Webb, J. \& Domansky, M. 2009, Fire and Stone. Science, 325: 820-821. doi:10.1126/science.1178014 